\title{
Soft tissue substitutes in non-root coverage procedures: a systematic review and meta-analysis
}

\author{
Kristina Bertl ${ }^{1,2}$ • Maximilian Melchard ${ }^{2} \cdot$ Nikolaos Pandis $^{3} \cdot$ Michael Müller-Kern $^{4}$. \\ Andreas Stavropoulos ${ }^{1}$ (i)
}

Received: 31 May 2016/Accepted: 22 December 2016/Published online: 20 January 2017

(C) The Author(s) 2017. This article is published with open access at Springerlink.com

\begin{abstract}
Objectives The present systematic review compared the effectiveness of soft tissue substitutes (STSs) and autogenous free gingival grafts (FGGs) in non-root-coverage procedures to increase keratinized tissue (KT) width around teeth.

Materials and methods Included studies fulfilled the following main eligibility criteria: (a) preclinical in vivo or human controlled trials using FGG as control, (b) non-root-coverage procedures, and (c) assessment of KT width. Meta-analysis was performed on the gain in KT width (primary outcome variable) and several secondary variables.

Results Eight human trials with short observation time evaluating five different STSs were identified. FGG yielded consistently significantly $(p<0.001)$ larger increase in KT width irrespective whether the comparison regarded an acellular matrix or a tissue-engineered STS. Further, FGG yielded consistently $\geq 2 \mathrm{~mm}$ KT width postoperatively, while use of STS did not, in the few studies reporting on this outcome. On the other hand, STSs resulted in significantly better aesthetic outcomes and received greater patient preference $(p<0.001)$.
\end{abstract}

Electronic supplementary material The online version of this article (doi:10.1007/s00784-016-2044-4) contains supplementary material, which is available to authorized users.

Andreas Stavropoulos

andreas.stavropoulos@mah.se

1 Department of Periodontology, Faculty of Odontology, University of Malmö, Carl Gustafs väg 34, 20506 Malmö, Sweden

2 Division of Oral Surgery, School of Dentistry, Medical University of Vienna, Vienna, Austria

3 Department of Orthodontics and Dentofacial Orthopedics, Dental School/Medical Faculty, University of Bern, Bern, Switzerland

4 Division of Conservative Dentistry and Periodontology, School of Dentistry, Medical University of Vienna, Vienna, Austria
Conclusions Based on relatively limited evidence, in nonroot-coverage procedures, FGG (1) resulted consistently in significantly larger increase in KT width compared to STS and (2) yielded consistently $\geq 2 \mathrm{~mm} \mathrm{KT}$ width postoperatively, while STSs did not. STSs yielded significantly better aesthetic outcomes, received greater patient preference, and appeared safe.

Clinical relevance Larger and more predictable increase in KT width is achieved with FGG, but STSs may be considered when aesthetics is important. Clinical studies reporting relevant posttreatment outcomes, e.g., postop KT width $\geq 2 \mathrm{~mm}$, on the long-term ( $>6$ months) are warranted.

Keywords Attached gingiva $\cdot$ Keratinized tissue . Meta-analysis $\cdot$ Randomized controlled trials $\cdot$ Soft tissue augmentation $\cdot$ Systematic review

\section{Background}

It is currently accepted that a minimum width of keratinized tissue (KT) around teeth is not necessary to maintain periodontal health and/or prevent gingival recession development, when adequate plaque control is performed. However, if plaque control is inadequate and/or a submarginal restoration is necessary, a minimum of $2 \mathrm{~mm}$ of KT (i.e., ca. $1 \mathrm{~mm}$ of free gingiva and $1 \mathrm{~mm}$ attached gingiva (AG)) is recommended [1]; hence, in such patients lacking $2 \mathrm{~mm} \mathrm{KT}$ width, soft tissue augmentation procedures should be considered (for review, see Scheyer et al. [2]).

Various non-root coverage procedures aiming to increase the width of KT in terms of apico-coronal dimension have been proposed through the years. These include various flap designs, usually in combination with autogenous soft tissue grafting. In a review performed a few years ago by Thoma 
et al. [3] the apically positioned flap (APF) in combination with an autogenous free gingival graft (FGG) from the palate was found to result in significantly higher increase in KT width compared to APF alone and marginally significant higher increase compared to APF in combination with a soft tissue substitute (STS). Grafting with FGG, however, has some major disadvantages: (1) need for second surgical site contributing to patient morbidity, (2) occasionally relatively limited supply, (3) some risk for surgical complications (i.e., intraoperative violation of the greater palatine vessels and nerves or a strong postoperative bleeding), and (4) often an unsatisfactory aesthetic outcome due to a "patch-like" appearance with significant color mismatch to the neighboring tissue. Thus, STSs appear as an attractive alternative to FGG.

Indeed, new STS products have appeared in the market since the review mentioned previously [3], and although all alternatives to a FGG have been summarized in the last AAP workshop [1], no recent meta-analysis is available on this specific comparison. Hence, the aim of the present study was to conduct a systematic review and meta-analysis to answer the following focused question, according to the population, intervention, comparison, outcomes, and study design criteria [4]: "In animal or human trials, are STSs equally efficacious as autogenous palatal soft tissue grafts (FGG or connective tissue grafts (CTG)) in non-root-coverage procedures aiming to increase the apico-coronal width of KT around teeth, including aesthetic and patient-reported outcome measures (PROMs)?"

\section{Materials and methods}

\section{Protocol and eligibility criteria}

The present systematic review followed the Preferred Reporting Items for Systematic Reviews and Meta-analyses (PRISMA; Appendix 1; [5, 6]). The following inclusion criteria were applied during literature search on original studies: (a) English or German language, (b) full text available, (c) preclinical in vivo trials or (d) human controlled or randomized controlled clinical trials (RCTs) with $\geq 5$ patients and $\geq 3$ month follow-up, (e) non-root coverage procedures, and (f) preoperative and postoperative assessment of the KT width. Studies were excluded if not all inclusion criteria were met and if they regarded in vitro studies or augmentation of KT in fully edentulous patients or around implants.

\section{Information sources and literature search}

Electronic search was performed on three sources (last search December 31, 2015; no date restriction used): Medline (PubMed), Embase (Ovid), and CENTRAL (Ovid). The database Medline (PubMed) was searched with the following keywords: (acellular dermal matrix OR dermal matrix allograft OR alloderm OR soft tissue graft OR free gingival graft OR human fibroblast-derived dermal substitute OR dermagraft OR apligraf OR collagen matrix OR extracellular membrane OR gingival autograft OR soft tissue augmentation OR soft tissue transplantation OR soft tissue correction) AND (keratinized tissue OR keratinized gingiva OR attached gingiva OR attached mucosa OR keratinized mucosa). For the other two databases, comparable terms were used but modified to be suitable for specific criteria of the particular database. Additionally, grey literature (conference abstracts and www. opengrey.eu) was browsed and a "manual search" through the electronically available material of the following relevant journals, including publications ahead of print, was performed: Journal of Clinical Periodontology, Journal of Periodontology, Journal of Periodontal Research, Clinical Oral Investigations, Journal of Dental Research, and Parodontologie. Screening of the reference lists of previous reviews and selected full texts was also conducted. Finally, a forward search via Science Citation Index of included papers was added and ClinicalTrials.gov was checked on unpublished or ongoing studies.

\section{Data collection and extraction}

Two authors (KB, MM) independently checked titles, abstracts, and finally full texts with regard to the predefined eligibility criteria. Abstracts with unclear methodology were included in full-text assessment to avoid exclusion of potentially relevant articles. One author $(\mathrm{KB})$ repeated the literature search. In case of ambiguity, consensus through discussion was achieved together with a third author (AS).

Two authors (KB, MM) extracted twice the following data (if reported): width of $\mathrm{KT}$ at baseline and after 3, 6, and 12 months and/or KT gain, difference in KT gain, and graft contraction; frequency of postintervention width of KT $\geq 2 \mathrm{~mm}$; and aesthetic (i.e., tissue color and texture) and PROMs (i.e., postoperative pain level and patient preference/satisfaction).

\section{Risk of bias assessment}

Two authors (MM, MMK) independently evaluated the risk of bias applying the Cochrane Collaboration's Tool for assessing risk of bias (Cochrane Handbook for Systematic Reviews of Interventions) [7]. The following domains were evaluated at "low," "high," or "unclear" risk of bias: (a) random sequence generation, (b) allocation concealment, (c) blinding of outcome assessment, (d) incomplete outcome data, (e) selective reporting, and (f) other bias. As the specific research question (comparison of an autologous palatal tissue graft with a STS) makes it impossible to blind the personnel during surgery and almost impossible to blind the patients, the criterion "blinding 
of participants and personnel," originally included in the tool, was excluded herein. The overall risk of bias for an individual study was judged as follows: low, if all criteria were evaluated to be of low risk; high if at least one criterion was evaluated to be of high risk; and unclear, if at least one criterion was evaluated to be of unclear risk but no criterion of high risk. One author (MM) repeated the assessment, and in case of ambiguity, consensus through discussion was achieved.

\section{Synthesis of results}

The postintervention mean difference between STS and autogenous palatal soft tissue graft groups, regarding gain in KT width (primary outcome variable) and several secondary variables [graft contraction, aesthetic outcome (i.e., tissue color and texture match to the neighboring tissue), and PROMs (i.e., pain level and preference/satisfaction)], was assessed by metaanalysis.

Clinical heterogeneity of included studies was gauged by assessing the treatment protocol, particularly participants and setting, materials used, timing of data collection, and measurement techniques. Statistical heterogeneity was assessed by graphic display and consistency of the estimated treatment effects from the included trials in conjunction with $95 \%$ confidence intervals (CIs). The chi-squared test was used to assess heterogeneity; a $p$ value $<0.1$ would be considered indicative of significant heterogeneity [8]. $I^{2}$ test for homogeneity was also undertaken, where possible, to quantify the extent of heterogeneity prior to each meta-analysis.

Quantitative synthesis was performed using the DerSimonian and Laird random effect methods [9] for all included studies and separately for comparing "acellular graft substitutes vs. FGG" and "tissue-engineered graft substitutes vs. FGG." A weighted mean pooled treatment effect was calculated with $95 \%$ CIs for the continuous outcome variables using a random effects model; a random effects model was considered more appropriate in view of the variation in population and settings. Pooled estimates were also calculated separately per follow-up period (i.e., 3, 6, and 12 months). Most comparisons (9/11) were derived from split-mouth studies, and in those instances where the standard deviation of the mean difference was not available, it was calculated using the formula

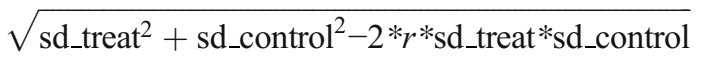

where sd_treat and sd_control are the corresponding standard deviations and $r$ is the correlation coefficient for the between treatment group measurements. The correlation coefficient was set at 0.5 ; however, syntheses were also conducted using values of $r=0$ in the context of sensitivity analyses. For binary outcomes (i.e., aesthetic outcome and PROMs), a similar adjustment was implemented using $r=0.5$ to calculate the variances on a logarithmic scale, before conversion to the exponentiated form.

\section{Results}

\section{Study selection}

The flowchart of the literature search is presented in Appendix 2. Out of 485 originally identified studies, 314 and 139 were excluded based on title and abstract, respectively. Seven additional records were retrieved from reference lists of previous reviews and selected full-text articles, and two were identified from the forward search. No unpublished or ongoing studies were identified. From the 41 articles selected for full-text review, 33 [References of excluded studies, 1-33] were excluded for various reasons (for details, see Appendix 3). Finally, eight clinical trials [10-17] were included; further on, the studies will be cited with Roman numbers as indicated in Table 1.

\section{Study characteristics}

\section{Study populations}

Sample size ranged from 5 to 96 patients; two studies (VI, VIII) excluded from the analysis some patients, which had initially been treated for training purposes. All studies reported patient age range, but one (III) reported mean age. Sex distribution was reported in seven studies (I-III, V-VIII). Smoking status was not reported in three studies (II-IV); four studies (V-VIII) included non-smokers and former smokers and one (I) only non-smokers (Table 1).

\section{Type of intervention}

Indication for treatment in all included studies was an insufficient zone of KT [two studies (II, V)] or of AG [six studies (I, III, IV, VI-VIII)]. All studies were RCTs [6 with split-mouth design (III-VIII)] and comparisons regarded "STSs and APF" vs. "FGG and APF." The follow-up period ranged from 3 to 12 months. All studies reported no patient loss to follow-up (Table 1).

\section{Type of autogenous soft tissue grafts and STSs}

All studies used FGG as the main control group, while one study (II) included a second control group with subepithelial CTG. The apico-coronal graft dimension in the control group was either predefined to 4-5 mm (V-VIII) or measured during grafting (I).

Five different STSs were tested: three acellular matrices [AlloDerm ${ }^{\circledR}$ (I, II); DynaMatrix ${ }^{\circledR}$ (III); Mucograft ${ }^{\circledR}$ (IV, $\mathrm{V})$ ] and two tissue-engineered STSs [CelTx ${ }^{\mathrm{TM}}$ (VII, VIII); 


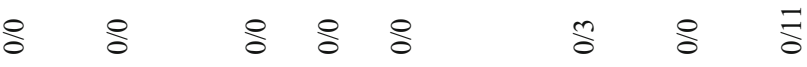

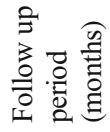

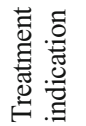

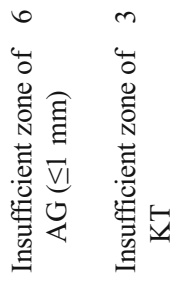

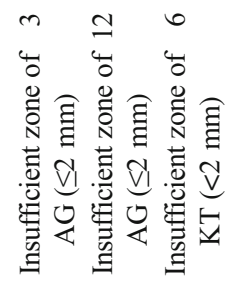

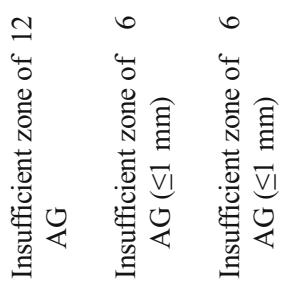

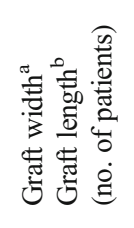

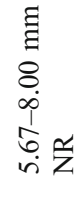

带.

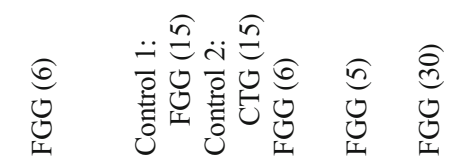

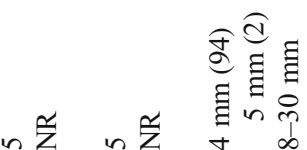

A

递

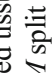

递

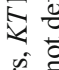

要

율

这

战

.5.

는

ब를

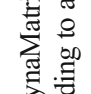

㱐

急莨

范

응

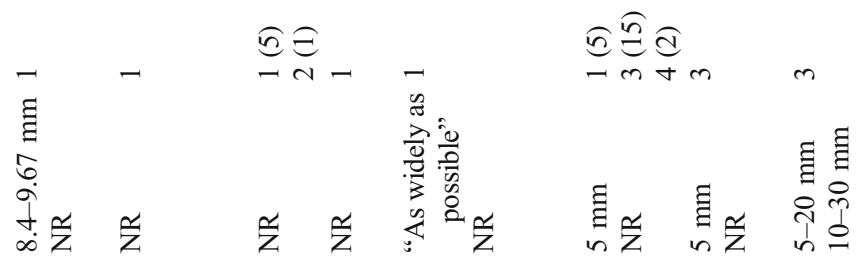

₹

宅

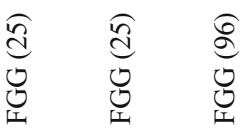

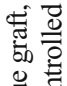

号

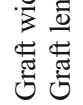

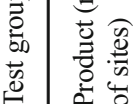

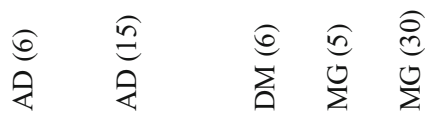

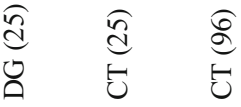

है

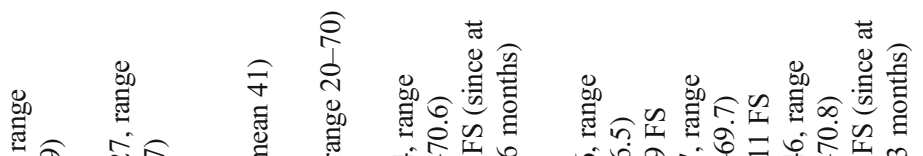
穴穴

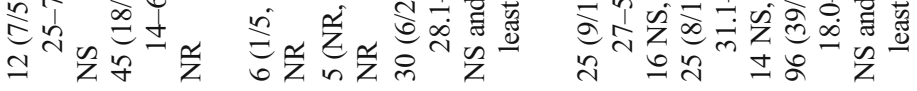

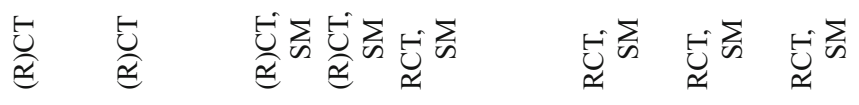

$-\quad \equiv \geq>$ 号 $5 \equiv$

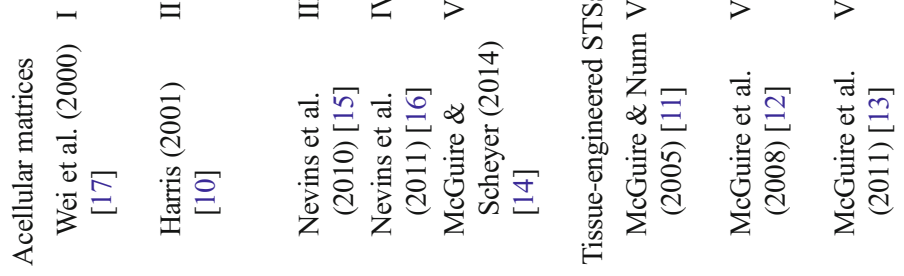

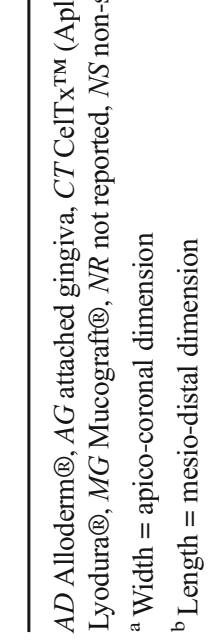


Dermagraft@ (VI)] (Table 2). The apico-coronal dimension of the STS was either predefined (5 mm) (VI, VII) or measured during grafting (I, VIII). Four studies (I, II, IV, V) used the STS in a single layer and two studies (VII, VIII) in three layers, and two studies (III, VI) tested various numbers of layers (Table 1). In seven studies (I-VII) no remarkable adverse events (AE) were reported. One study (VIII) included a detailed AE report: in two patients, the polycarbonate membrane on which CelTx ${ }^{\mathrm{TM}}$ is supplied was unintentionally used; a third patient showed a mouth ulceration; another three serious AE (e.g., pneumonia, chest pain) were considered unrelated to the intervention. Currently, Dermagraft ${ }^{\circledR}$ is not available in the market and CelTx ${ }^{\mathrm{TM}}$ is not distributed for dental use (Table 2).

\section{Type of reported outcome variables}

Apart from KT width, only two studies (I, VI) assessed graft contraction quantitatively (Table 3). Regarding PROMs, most studies performed a qualitative assessment; e.g., only three studies (V, VI, VIII) evaluated specifically tissue color and texture after treatment by scoring clinical photographs or direct clinical examination using calibrated examiners, while in five studies (I-IV, VII), only a description by the authors was given (Table 4). Similarly, the pain associated with the intervention (II, III, VI-VIII) or patient preference regarding the intervention (IV-VIII) was assessed by simply asking the patients (Table 5).

\section{Results on KT width}

Five studies [RoB: low (VII); unclear (I); high (II-IV)] presented a significant increase in KT width from baseline to final evaluation values (i.e., comparison "A" in Table 3). In the STS and FGG groups, the increase in KT width ranged from 1.26 to $4.1 \mathrm{~mm}$ and from 2.57 to $5.57 \mathrm{~mm}$, respectively. Five studies [RoB: low (V, VII, VIII); unclear (I); high (VI)] found significantly wider KT in the FGG group at final evaluation (i.e., comparison "B" in Table 3). Six studies compared gain in KT width between the groups (i.e., comparison " $\mathrm{C}$ " in Table 3); four studies [RoB: low (V, VII), unclear (I); high (III)] showed significantly larger gain in the FGG group. Regarding presence of $\geq 2 \mathrm{~mm} \mathrm{KT}$ after treatment, three studies [RoB: low (VII); high (II, III)] reported a frequency of $100 \%$ for FGG, four studies [RoB: low (V, VII, VIII); high (III)] reported a frequency of $76-100 \%$ for STSs, and one study [high RoB (II)] reported a range of 1.5-8.5 mm KT width, i.e., $<100 \%$ frequency, for STS. Graft contraction was reported in two studies [RoB: unclear (I); high (VI)] (Table 3) and was significantly higher ( 2 and 4.4 times, respectively) in the STS group.

\section{Results on PROMs}

In all studies, but one (II), significantly better color and texture match of the grafted region with the neighboring tissues was reported for the STS group compared to the FGG group, both when judged by the patients [RoB: low (V, VIII)); high (VI)] or the authors [RoB: low (VII); unclear (I); high (III, IV)]. In general, color and texture match was achieved in about $90 \%$ of the cases in the STS group, while the tissue color was less red and the texture was less firm in the grafted area in $>70$ and $>45 \%$ of the cases, respectively, in the FGG group (Table 4). In the last study [high RoB (II)], the authors judged the appearance of the STS also as patch like, similarly to the FGG group.

No significant difference between STS and FGG regarding the level of pain experienced by the patient was reported in two studies [RoB: low (VIII); high (VI)]; however, one (VI) of the studies assessed pain only after 3 months postoperatively. In all studies, but one [high RoB (VI)], a significant difference in favor of the STS (range 60-76.5\%) regarding patient preference was reported [low RoB (V, VII, VIII)] (Table 5).

\section{Synthesis of results}

\section{KT width}

Pooled comparisons (Fig. 1a) Regarding the comparison between any kind of STS and FGG, the overall pooled estimate (i.e., not considering the time point of comparison) was $-1.55 \mathrm{~mm}$ favoring FGG $(p<0.001)$, but with significant heterogeneity. In the sensitivity analysis where $r$ was set at an extreme $r=0$, overall pooled estimate remained significant in favor of FGG with $-1.55 \mathrm{~mm}(95 \%$ CIs $-1.90,-1.20$, $p<0.001)$. The predictive intervals for the overall pooled estimate indicated that the KT width achieved with STS in a future trial is likely to be -2.57 to $-0.54 \mathrm{~mm}$ less than what would be achieved with FGG.

\section{Comparisons between FGG and acellular matrices} (Fig. 1b) For comparison between FGG and acellular matrices, the overall pooled estimate was $-1.64 \mathrm{~mm}$ favoring $\mathrm{FGG}$ ( $p<0.001)$, but with significant heterogeneity. In the sensitivity analysis where $r$ was set at an extreme $r=0$, overall pooled estimate remained significant with $-1.61 \mathrm{~mm}$ (95\% CIs -2.33 , $-0.90, p<0.001)$.

\section{Comparisons between FGG and tissue-engineered STSs} (Fig. 1c) For comparison between FGG and tissueengineered STSs, the overall pooled estimate was $-1.48 \mathrm{~mm}$ favoring FGG $(p<0.001)$, but heterogeneity was significant. In the sensitivity analysis where $r$ was set at an extreme $r=0$, overall pooled estimate remained significant with $-1.48 \mathrm{~mm}$ (95\% CIs $-1.83,-1.12, p<0.001)$. 
Table 2 Characteristics of the tested STSs

\begin{tabular}{|c|c|c|c|c|}
\hline Product name & Origin of the material & Company & Product sold in & Adverse events \\
\hline \multicolumn{5}{|l|}{ Acellular matrices } \\
\hline AlloDerm® & $\begin{array}{l}\text { Human freeze-dried, cell-free, } \\
\text { dermal matrix }\end{array}$ & $\begin{array}{l}\text { LifeCell Corp., Branchburg, NJ, } \\
\text { USA }\end{array}$ & $\begin{array}{l}\text { USA, distributed in the EU via } \\
\text { HTA }\end{array}$ & None \\
\hline $\begin{array}{l}\text { DynaMatri- } \\
\mathrm{x}{ }^{\circledR}\end{array}$ & $\begin{array}{l}\text { Porcine small intestinal } \\
\text { submucosa } \\
\text { (collagens, } \\
\text { glycosaminoglycans, } \\
\text { glycoproteins, proteoglycans, } \\
\text { growth factors) }\end{array}$ & $\begin{array}{l}\text { Keystone Dental, Turnpike } \\
\text { Burlington, MA, USA }\end{array}$ & USA and Europe since 2008 & None \\
\hline Mucograft® & Porcine bilayer collagen matrix & $\begin{array}{l}\text { Geistlich Pharma, Wolhusen, } \\
\text { Switzerland }\end{array}$ & USA and EMEA since 2010 & None \\
\hline \multicolumn{5}{|l|}{ Tissue engineered } \\
\hline $\begin{array}{l}\text { CelTx }{ }^{\mathrm{TM}} \\
\quad \text { (Apligraf®) }\end{array}$ & $\begin{array}{l}\text { Living cellular construct } \\
\text { composed of human } \\
\text { fibroblasts, keratinocytes, and } \\
\text { extracellular } \\
\text { matrix proteins on type I } \\
\text { bovine collagen }\end{array}$ & Organogenesis, Canton, MA, USA & $\begin{array}{l}\text { FDA approved, but not } \\
\text { distributed for dental use }\end{array}$ & $\begin{array}{l}24 \text { patients reported }>1 \\
\text { adverse event } \\
\text { (total of } 43 \text { events, no } \\
\text { event } \\
\text { reported by }>2 \\
\text { patients); } 3 \text { patients } \\
\text { reported adverse } \\
\text { events at LCC site } \\
\text { (McGuire et al. 2011) } \\
\text { [13] }\end{array}$ \\
\hline Dermagraft $®$ & $\begin{array}{l}\text { Living human fibroblast-derived } \\
\text { dermal substitute }\end{array}$ & $\begin{array}{l}\text { Advanced Tissue Sciences, Inc., } \\
\text { La Jolla, CA, USA }\end{array}$ & Withdrawn from the market & None \\
\hline
\end{tabular}

FDA Food and Drug Administration, HTA Human Tissue Authority, EMEA Europe, Middle East, Africa

\section{Graft contraction}

Since the last review [3], no new data were available on the parameter "graft contraction." There, it was reported that STSs showed significantly larger ( $28.4 \%$ on average) contraction compared to that observed in FGG.

\section{Tissue color and texture match (Fig. 2a, b)}

The overall pooled estimate of the OR for tissue color match in the grafted region with the neighboring tissue was 37.84 favoring STSs $(p<0.001)$; heterogeneity was low. Similar, the overall pooled estimate of the OR for tissue texture match was 70.12 again favoring STSs $(p<0.001)$; heterogeneity was significant.

\section{Patient preference (Fig. 2c)}

The overall pooled estimate of the OR was 8.74 favoring STSs $(p<0.001)$; heterogeneity was low.

\section{RoB assessment}

Since less than ten studies were included in the meta-analysis, standard funnel plots and contour-enhanced funnel plots [18] were not possible to use to examine publication bias. Three studies (V, VII, VIII) were assessed as of low, one study (I) of unclear, and four studies (II, III, IV, VI) of high RoB. RoB analysis of each of the included studies and overall risk are presented in Appendixes 4 and 5. Further, four studies (I, II, III, IV) were described by the authors as RCTs, but the randomization process was not defined. Reasons for assigning "other bias" to the various studies are also included in Appendix 4.

\section{Discussion}

The results of the present systematic review indicate that, on the basis of relatively limited clinical evidence, the use of a STS is inferior than the use of a FGG harvested from the palate in increasing the width of KT in non-root coverage procedures, when combined with APF. However, better color and texture match of the grafted area with the neighboring tissues is consistently observed with STSs.

The necessity or not to have a minimum amount of $A G$ in order to sustain periodontal health has been debated in the past [19-26]. In particular, based on the observation made in a clinical study that despite daily (professionally delivered) prophylaxis, plaque-free tooth surfaces with $<2 \mathrm{~mm}$ of KT continued to exhibit clinical signs of inflammation, it was widely suggested that $\geq 2 \mathrm{~mm} \mathrm{KT}$ is a requirement for periodontal tissue stability [21]. In other clinical studies, however, patients with limited amount of KT (even with $<1 \mathrm{~mm}$ ) did not experience 
Table 3 Values of the width of keratinized tissue $(\mathrm{mm})$ at baseline and final evaluation, postintervention gain (mm), mean difference in gain (mm) between test and control groups, graft contraction (\%), and frequency of postintervention KT width $\geq 2 \mathrm{~mm}(\%)$

\begin{tabular}{|c|c|c|c|c|c|c|c|c|}
\hline \multirow[t]{2}{*}{ Study (year) } & \multirow[t]{2}{*}{ Group } & \multirow[t]{2}{*}{ Baseline (mm) } & \multicolumn{4}{|l|}{ Final evaluation } & \multirow{2}{*}{$\begin{array}{l}\text { Graft } \\
\text { contraction } \\
(\%)\end{array}$} & \multirow{2}{*}{$\begin{array}{l}\text { Frequency of } \\
\text { postintervention } \\
\text { KT width } \geq 2 \mathrm{~mm} \\
\text { (range or } 95 \% \mathrm{CI} \\
\text { of } \\
\text { postintervention } \\
\text { KT width) }\end{array}$} \\
\hline & & & Values (mm) & Gain (mm) & $\begin{array}{l}\text { Mean } \\
\text { difference in } \\
\text { gain }(\mathrm{mm})\end{array}$ & $\begin{array}{l}\text { Comparison } \\
\text { based on }\end{array}$ & & \\
\hline \multicolumn{9}{|l|}{ Acellular matrices } \\
\hline \multirow{2}{*}{$\begin{array}{l}\text { Wei et al. } \\
\quad(2000) \text { [17] }\end{array}$} & Test & $0.68 \pm 0.26^{\mathrm{a}}$ & $3.25 \pm 0.89^{\mathrm{a}}$ & $2.59 \pm 0.92^{\mathrm{a}}$ & $2.98^{\mathrm{c}}$ & $A, B, C$ & $71 \pm 10^{\mathrm{a}}$ & NR \\
\hline & Control & $0.57 \pm 0.41^{\mathrm{a}}$ & $6.15 \pm 0.49^{\mathrm{a}}$ & $5.57 \pm 0.44^{\mathrm{a}}$ & & & $16 \pm 12^{\mathrm{a}}$ & NR \\
\hline \multirow[t]{3}{*}{$\begin{array}{l}\text { Harris (2001) } \\
{[10]}\end{array}$} & Test & $0.6 \pm 0.87^{\mathrm{a}}$ & $4.7 \pm 1.92^{\mathrm{a}}$ & $4.1 \pm 1.79^{\mathrm{a}}$ & & $A, \mathrm{C}$ & $\mathrm{NR}$ & $\begin{array}{l}<100 \%(\text { range } \\
1.5-8.5 \mathrm{~mm})\end{array}$ \\
\hline & $\begin{array}{l}\text { Control } \\
\text { (FGG) }\end{array}$ & $0.8 \pm 0.59^{\mathrm{a}}$ & $4.8 \pm 1.16^{\mathrm{a}}$ & $4.1 \pm 1.25^{\mathrm{a}}$ & $0.00^{\mathrm{c}}$ & & & $\begin{array}{l}100 \% \text { (range } \\
3.0-6.5 \mathrm{~mm})\end{array}$ \\
\hline & $\begin{array}{l}\text { Control } \\
\text { (CTG) }\end{array}$ & $0.4 \pm 0.47^{\mathrm{a}}$ & $4.0 \pm 0.99^{\mathrm{a}}$ & $3.6 \pm 0.82^{\mathrm{a}}$ & $0.50^{\mathrm{c}}$ & & & $\begin{array}{l}100 \%(\text { range } \\
2.5-5.5 \mathrm{~mm})\end{array}$ \\
\hline \multirow[t]{2}{*}{$\begin{array}{l}\text { Nevins et al. } \\
\quad(2010) \text { [15] }\end{array}$} & Test & $0.8 \pm 0.7^{\mathrm{a}}$ & $3.4 \pm 0.8^{\mathrm{a}}$ & $2.6 \pm 1.1^{\mathrm{a}}$ & $2.7^{\mathrm{c}}$ & $A, C$ & NR & $\begin{array}{l}100 \% \text { (range } \\
2.5-5.0 \mathrm{~mm})\end{array}$ \\
\hline & Control & $1.1 \pm 1.1^{\mathrm{a}}$ & $6.4 \pm 0.9^{\mathrm{a}}$ & $5.3 \pm 1.3^{\mathrm{a}}$ & & & & $\begin{array}{l}100 \% \text { (range } \\
5.0-8.0 \mathrm{~mm} \text { ) }\end{array}$ \\
\hline \multirow{2}{*}{$\begin{array}{l}\text { Nevins et al. } \\
\text { (2011) [16] }\end{array}$} & Test & NR & $N R$ & $2.3 \pm 1.1^{\mathrm{a}}$ & $0.80^{\mathrm{c}}$ & $A, \mathrm{C}$ & NR & NR \\
\hline & Control & NR & $N R$ & $3.1 \pm 0.6^{\mathrm{a}}$ & & & & NR \\
\hline \multirow[t]{2}{*}{$\begin{array}{l}\text { McGuire \& } \\
\text { Scheyer } \\
\text { (2014) [14] }\end{array}$} & Test & $0.88 \pm 0.61^{\mathrm{a}}$ & $2.92 \pm 0.88^{\mathrm{a}}$ & $2.04^{\mathrm{c}}$ & $1.61^{\mathrm{c}}$ & $B, C$ & NR & $\begin{array}{l}96.67 \%(95 \% \mathrm{CI} \\
2.59-3.25 \mathrm{~m}- \\
\mathrm{m})\end{array}$ \\
\hline & Control & $0.77 \pm 0.68^{\mathrm{a}}$ & $4.42 \pm 0.64^{\mathrm{a}}$ & $3.65^{\mathrm{c}}$ & & & & $\begin{array}{l}\text { NR }(95 \% \text { CI } \\
\quad 4.18-4.66 \mathrm{~m}- \\
\text { m) }\end{array}$ \\
\hline \multicolumn{9}{|l|}{ Tissue engineered } \\
\hline \multirow[t]{2}{*}{$\begin{array}{l}\text { McGuire \& } \\
\text { Nunn (2005) } \\
\text { [11] }\end{array}$} & Test & $1.46 \pm 0.91^{\mathrm{a}}$ & $\begin{array}{l}2.72 \\
\quad(2.42-3.03)^{\mathrm{b}}\end{array}$ & $1.26^{\mathrm{c}}$ & $1.31^{\mathrm{c}}$ & $B$ & $\begin{array}{l}45.5 \\
\quad(39.5-51.4)^{\mathrm{b}}\end{array}$ & $\begin{array}{l}\text { NR }(95 \% \text { CI } \\
2.42-3.03 \mathrm{~m}- \\
\mathrm{m})\end{array}$ \\
\hline & Control & $1.34 \pm 0.97^{\mathrm{a}}$ & $\begin{array}{l}3.91 \\
\quad(3.61-4.22)^{\mathrm{b}}\end{array}$ & $2.57^{\mathrm{c}}$ & & & $\begin{array}{l}21.8 \\
\quad(15.9-27.7)^{\mathrm{b}}\end{array}$ & $\begin{array}{l}\mathrm{NR}(95 \% \mathrm{CI} \\
\quad 3.61-4.22 \mathrm{~m}- \\
\mathrm{m})\end{array}$ \\
\hline \multirow[t]{2}{*}{$\begin{array}{l}\text { McGuire et al. } \\
\quad(2008) \text { [12] }\end{array}$} & Test & $\begin{array}{l}1.07 \\
\quad(0.89-1.25)^{\mathrm{b}}\end{array}$ & $\begin{array}{l}2.40 \\
\quad(2.08-2.72)^{\mathrm{b}}\end{array}$ & $\begin{array}{l}1.33 \\
\quad(0.95-1.71)^{\mathrm{b}}\end{array}$ & $1.96^{\mathrm{c}}$ & $A, B, C$ & NR & $\begin{array}{l}76 \%(95 \% \text { CI } \\
2.08-2.72 \mathrm{~m}- \\
\mathrm{m})\end{array}$ \\
\hline & Control & $\begin{array}{l}1.17 \\
\quad(0.99-1.35)^{\mathrm{b}}\end{array}$ & $\begin{array}{l}4.46 \\
\quad(4.14-4.78)^{\mathrm{b}}\end{array}$ & $\begin{array}{l}3.29 \\
\quad(2.91-3.68)^{\mathrm{b}}\end{array}$ & & & & $\begin{array}{l}100 \%(95 \% \mathrm{CI} \\
\quad 4.14-4.78 \mathrm{~m}- \\
\mathrm{m})\end{array}$ \\
\hline \multirow{2}{*}{$\begin{array}{l}\text { McGuire et al. } \\
\text { (2011) [13] }\end{array}$} & Test & $1.41 \pm 0.72^{\mathrm{a}}$ & $3.21 \pm 1.14^{\mathrm{a}}$ & $1.80^{\mathrm{c}}$ & $1.34^{\mathrm{c}}$ & $B$ & NR & $95.3 \%(\mathrm{NR})$ \\
\hline & Control & $1.43 \pm 0.69^{\mathrm{a}}$ & $4.57 \pm 1.00^{\mathrm{a}}$ & $3.14^{\mathrm{c}}$ & & & & NR \\
\hline
\end{tabular}

Italic values indicate significant difference $(p<0.05)$

$C T G$ connective tissue graft, $F G G$ free gingival graft, $K T$ keratinized tissue, $N R$ not reported, $S D$ standard deviation, $A$ comparisons between baseline and final evaluation values, $B$ comparisons between groups regarded values of KT width at the final evaluation, $C$ comparisons between groups regarded values of KT width gain

${ }^{\mathrm{a}}$ Mean $( \pm \mathrm{SD})$

${ }^{\mathrm{b}}$ Mean $(95 \% \mathrm{CI})$

${ }^{\mathrm{c}}$ Mean (calculation based on the presented data)

any attachment loss over a longer period of time [19, 22]. In context, in a systematic evaluation employing a preclinical in vivo model $[25,26]$, it was demonstrated that periodontal tissues can be maintained clinically and histologically inflammation free, irrespective of the presence or absence of a wide zone of KT, provided that effective plaque control is performed; 
Table 4 Tissue color and texture in STS and FGG groups at final evaluation

\begin{tabular}{|c|c|c|c|c|c|c|c|}
\hline \multirow[t]{2}{*}{ Study (year) } & \multirow[t]{2}{*}{ Group } & \multicolumn{3}{|c|}{ Tissue color } & \multicolumn{3}{|c|}{ Tissue texture } \\
\hline & & Less & Equally & More & Less & Equally & More \\
\hline & & Red ( & & & Firm & & \\
\hline \multirow[t]{2}{*}{ McGuire \& Nunn $(2005)^{\mathrm{a}}[11]$} & STS & 9.1 & 90.9 & 0.0 & 9.1 & 90.9 & 0.0 \\
\hline & FGG & 68.2 & 27.3 & 4.6 & 77.3 & 22.7 & 0.0 \\
\hline \multirow[t]{3}{*}{ McGuire et al. $(2011)^{\mathrm{b}}[13]$} & STS & 2.4 & 92.9 & 4.7 & 0.0 & 95.3 & 4.7 \\
\hline & FGG & 72.9 & 27.1 & 0.0 & 45.9 & 54.1 & 0.0 \\
\hline & & \multicolumn{6}{|c|}{ Match to neighboring tissue (\%) } \\
\hline \multirow[t]{3}{*}{ McGuire \& Scheyer (2014) [14] } & STS & \multicolumn{3}{|c|}{87} & \multicolumn{3}{|l|}{97} \\
\hline & FGG & \multicolumn{3}{|l|}{10} & \multicolumn{3}{|l|}{0} \\
\hline & & \multicolumn{6}{|c|}{ Authors' description of the STS group ${ }^{c}$} \\
\hline \multicolumn{2}{|l|}{ Wei et al. (2000) [17] } & \multicolumn{3}{|c|}{$\begin{array}{l}\text { "Appears similar to the } \\
\text { alveolar mucosa" }\end{array}$} & \multicolumn{3}{|c|}{$\begin{array}{l}\text { "Appears similar to the alveolar } \\
\text { mucosa" }\end{array}$} \\
\hline \multicolumn{2}{|l|}{ Harris et al. (2001) [10] } & \multicolumn{3}{|c|}{ NR } & \multicolumn{3}{|c|}{$\begin{array}{l}\text { "CTG and AD seemed to produce a } \\
\text { more aesthetic result in most } \\
\text { cases; however, both produced a } \\
\text { result that was as 'patch like' in } \\
\text { appearance as a FGG" }\end{array}$} \\
\hline \multicolumn{2}{|l|}{ McGuire et al. (2008) [12] } & \multicolumn{3}{|c|}{$\begin{array}{l}\text { "Significant better } \\
\text { matching" }\end{array}$} & \multicolumn{3}{|c|}{ "Significant better matching" } \\
\hline \multicolumn{2}{|l|}{ Nevins et al. (2010) [15] } & \multicolumn{3}{|c|}{ "Excellent color blend" } & \multicolumn{3}{|c|}{ "Excellent texture blend" } \\
\hline \multicolumn{2}{|l|}{ Nevins et al. (2011) [16] } & \multicolumn{3}{|c|}{ "Excellent color blend" } & \multicolumn{3}{|c|}{ "Excellent texture blend" } \\
\hline
\end{tabular}

Italic values indicate significant difference between the test and control groups $(p<0.05)$

$A D$ Alloderm ${ }^{\circledR}, C T G$ connective tissue graft, $F G G$ free gingival graft, $N R$ not reported

${ }^{\text {a }}$ Recorded 12 months after treatment

${ }^{\mathrm{b}}$ Recorded 6 months after treatment

${ }^{\mathrm{c}}$ Data and evaluation parameters are not presented in contrast, in the presence of plaque, inflammation is clinically (but not histologically) more pronounced at sites with a narrow zone of KT, compared to sites with wide and firm AG. Nevertheless, it has also been reported that, in patients failing to attend supportive periodontal treatment on a regular basis, sites with a narrow zone of KT width (i.e., $1.4 \mathrm{~mm}$ on average) presented with an increased gingival index and lost attachment over a period of 6 years, although of questionable clinical magnitude (i.e., $0.5 \mathrm{~mm}$ ); in contrast, contralateral sites previously augmented and presenting a wide zone of KT did not show any deterioration of their periodontal conditions [27]. Altogether, surgical augmentation of the width of KT in non-root coverage procedures has nowadays rather limited indications; as already mentioned, it was suggested in a recent consensus conference that only in patients where plaque control is inadequate and/or submarginal restoration margins are necessary, soft tissue augmentation procedures should be considered for sites lacking $2 \mathrm{~mm} \mathrm{KT}$ width (for review, see Scheyer et al. [2]).

Although the use of FGG in combination with APF has been proven to be a predictable technique for increasing KT width on the long term $[28,29]$, the drawbacks associated with the procedure (i.e., second surgical site; limited supply; surgical complications; often unsatisfactory aesthetic outcome) have generated the pursuit of STSs. Indeed, various types of
STSs have been proposed and evaluated in the clinic; these include allogeneic and xenogeneic collagen-based matrices (AlloDerm ${ }^{\circledR}$, DynaMatrix ${ }^{\circledR}$, Mucograft $\AA$ ) and tissueengineered constructs including allogeneic cells seeded in xenogeneic matrices (CelTx ${ }^{\mathrm{TM}}$, Dermagraft $\AA$ ). The rationale of using tissue-engineered STSs is that the transplanted cells, which are not supposed to survive at the recipient site, provide a superior wound healing environment by secreting various anti-inflammatory cytokines and growth factors, including pro-angiogenic factors [30-33]. The results of the present meta-analysis revealed that use of a STS results in about 1.1-2.2 mm less KT width increase compared to the use of a FGG. Further, use of a tissue-engineered STS was apparently not superior to the use of an acellular matrix. Specifically, average KT gain after the use of tissue-engineered STSs was never $>2 \mathrm{~mm}$ [11-13], while it ranged between 2.0 and $4.1 \mathrm{~mm}$ after the use of acellular matrices [10,14-17]. This underperformance of STS compared to FGG is also depicted by the significantly larger (by 28\%) contraction of STS compared to that of FGG [3]. The results herein indicated also that the use of an STS does not predictably result in a KT width $\geq 2 \mathrm{~mm}$ after treatment. Only in one [15] out of four reporting studies, $100 \%$ of the sites treated with STS showed $\geq 2 \mathrm{~mm}$ of $\mathrm{KT}$, while in all three reporting studies, $100 \%$ of the sites 
Table 5 Patient-reported outcome measures on pain level and preference/satisfaction

\begin{tabular}{|c|c|c|c|c|c|c|}
\hline \multirow[t]{2}{*}{ Study (year) } & \multirow[t]{2}{*}{ Group } & \multicolumn{4}{|l|}{ Pain level } & \multirow[t]{2}{*}{ Patient preference/satisfaction } \\
\hline & & None $(\%)$ & Mild (\%) & Moderate $(\%)$ & Severe $(\%)$ & \\
\hline \multirow[t]{3}{*}{ McGuire \& Nunn $(2005)^{\mathrm{a}}[11]$} & STS & 13.6 & 50.0 & 31.8 & 4.6 & $9.91 \pm 1.54^{\mathrm{b}}$ \\
\hline & FGG & 13.6 & 54.6 & 27.3 & 4.6 & $10.20 \pm 1.13^{\mathrm{b}}$ \\
\hline & & After 3 day & & After 7 days $(\%$ & & \\
\hline \multirow[t]{3}{*}{ McGuire et al. $(2011)^{\mathrm{c}}[13]$} & STS & 70.6 & & 45.9 & & $76.5 \%$ \\
\hline & FGG & 62.3 & & 37.7 & & $23.5 \%$ \\
\hline & & Authors' d & ription $^{\mathrm{d}}$ & & & \\
\hline \multirow[t]{2}{*}{ Harris (2001) [10] } & $\begin{array}{l}\text { STS } \\
\text { FGG }\end{array}$ & \multirow{2}{*}{\multicolumn{4}{|c|}{$\begin{array}{l}\text { "Higher pain levels in the FGG group from the donor site... These } \\
\text { patients tended to take more pain medication and for a longer } \\
\text { period of time." }\end{array}$}} & NR \\
\hline & CTG & & & & & \\
\hline \multirow[t]{2}{*}{ McGuire et al. (2008) [12] } & STS & \multirow{2}{*}{\multicolumn{4}{|c|}{$\begin{array}{l}\text { "Subject perception of the duration of pain was reduced in the } \\
\text { STS sites." }\end{array}$}} & $60 \%$ \\
\hline & FGG & & & & & $20 \%$ (no preference $20 \%$ ) \\
\hline Nevins et al. (2010) [15] & $\begin{array}{l}\text { STS } \\
\text { FGG }\end{array}$ & \multicolumn{4}{|c|}{$\begin{array}{l}\text { "Patients reported less discomfort related to the palatal harvest } \\
\text { with the DynaMatrix when compared to the autogenous sites." }\end{array}$} & NR \\
\hline \multirow[t]{2}{*}{ McGuire \& Scheyer (2014) [14] } & STS & \multirow{2}{*}{\multicolumn{4}{|c|}{ NR }} & $70 \%$ \\
\hline & FGG & & & & & $30 \%$ \\
\hline \multirow[t]{2}{*}{ Nevins et al. (2011) [16] } & STS & \multirow{2}{*}{\multicolumn{4}{|c|}{ NR }} & Authors' description ${ }^{\mathrm{d}}$ \\
\hline & FGG & & & & & $\begin{array}{l}\text { "Significant bias toward avoiding palatal } \\
\text { harvesting, in favor of the STS group" }\end{array}$ \\
\hline Wei et al. (2000) [17] & $\begin{array}{l}\text { STS } \\
\text { FGG }\end{array}$ & \multicolumn{4}{|l|}{ NR } & NR \\
\hline
\end{tabular}

Italic values indicate significant difference between STS and FGG groups $(p<0.05)$

$C T G$ connective tissue graft, $F G G$ free gingival graft, $N R$ not reported, $S D$ standard deviation

${ }^{\text {a }}$ Pain level at 3 months after treatment (=first evaluation time point)

${ }^{\mathrm{b}}$ Mean $( \pm \mathrm{SD})$ of a specific not clearly defined scale

${ }^{\mathrm{c}}$ Pain at recipient site

${ }^{\mathrm{d}}$ Data and evaluation parameters are not presented

treated with FGG had $\geq 2 \mathrm{~mm} \mathrm{KT}$ width $[10,15]$. In perspective, despite the fact that the rationale for performing an augmentation procedure is to achieve KT width $\geq 2 \mathrm{~mm}$, only half of all included studies reported on the frequency of this outcome.

On the other hand, all but one [10] of the included studies revealed that better tissue color and texture match of the grafted site with the neighboring tissue was achieved with the use of a STS compared to that of a FGG [11-17]. Specifically, color and texture match was achieved in about $90 \%$ of the cases treated with a STS, while color and texture mismatch occurred in $>70$ and $>45 \%$, respectively, of the cases treated with a FGG. This finding of poor tissue color and texture match after the use of FGG is by far not surprising, since it is for long known that FGG preserves the histological characteristics of the donor site after transplantation [34]. Similarly, most studies reporting on patient preference described a significant difference in favor of the use of STS [12-14], while only one study [11] described no difference. Indeed, no remarkable adverse reactions were observed, thus raising no safety concerns for the use of STS. It seems reasonable to assume that patients favored STS due to less discomfort and/or pain compared to the use of a FGG. Nevertheless, in the two studies [11, 13], where pain was assessed using a validated instrument, no difference was recorded between the treatment groups. It has, however, to be mentioned that the use of a split-mouth design (as several studies herein [11-14]) may bring bias in pain assessment [35-37]. Again, it is interesting to note that despite the fact that less discomfort and/or pain and better aesthetic results are among the incentives to use STS instead of a FGG, these parameters were systematically and/or properly evaluated only in a fraction of the included studies.

In addition, limited standardization and large variability were observed among the studies regarding various factors related to the surgical procedure, e.g., the size of the recipient bed and/or application of single or multiple STS layers, which appear to influence the outcome and might be responsible for the significant heterogeneity that was frequently observed. Particularly, improved results in KT width gain have been reported with increased mesio-distal graft dimension [12] (i.e., treatment of multiple teeth) and the use of a multi-layer 
Fig. 1 a-c Forest plot on the effect size of treatment after application of a FGG (=control) compared to a all tested graft substitutes, $\mathbf{b}$ an acellular matrix, or $\mathbf{c}$ a tissue-engineered STS

(=treatment) overall and after 3, 6, and 12 months a
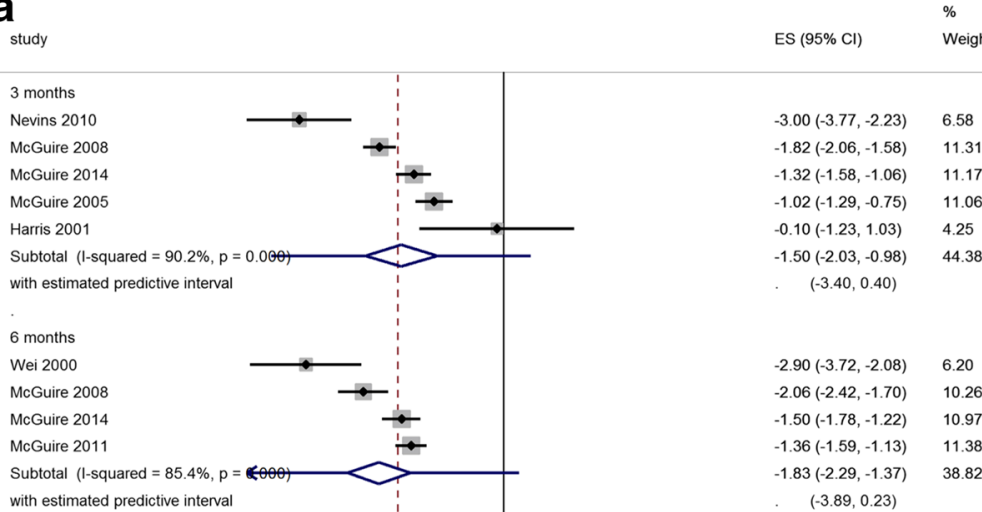

with estimated predictive interval

12 months

McGuire 2005

Nevins 2011

Subtotal (I-squared $=0.0 \%, p=0 \leqslant 9 \theta)$

Inestimable predictive distribution with $<3$ studies

Overall (I-squared $=85.6 \%, p=0.000$ ) with estimated predictive interval

NOTE: Weights are from random effects analysis
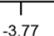

b

stud

ES (95\% Cl) Weight

3 months

Nevins 2010

McGuire 2014

Harris 2001

Subtotal $(1-$ squared $=90.9 \%, p=0.000)$

6 months

Wei 2000

McGuire 2014

Subtotal $(1-$ squared $=90.1 \%, p=0.001)$

12 months

Nevins 2011

Subtotal $(1-$-squared $=. \%, \mathrm{p}=$.)

Overall (1-squared $=86.3 \%, p=0.000)$

NOTE: Weights are from random effects analysis

1
-3.77

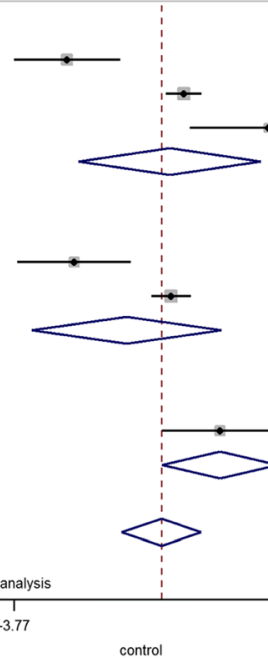

$-3.00(-3.77,-2.23)$

$-1.32(-1.58,-1.06) \quad 21.13$

$-0.10(-1.23,1.03) \quad 11.84$

$-1.52(-2.83,-0.21) \quad 48.76$

$-2.90(-3.72,-2.08) \quad 15.24$

$-1.50(-1.78,-1.22) \quad 20.95$

$-2.15(-3.51,-0.78) \quad 36.19$

$-0.80(-1.63,0.03) \quad 15.05$

$-0.80(-1.63,0.03) \quad 15.05$

$-1.64(-2.21,-1.07) \quad 100.00$

C

ES $(95 \% \mathrm{Cl}) \quad$ Weight

3 months

McGuire 2008

McGuire 2005

Subtotal (1-squared $=94.7 \%, p=0.000$ )

6 months

McGuire 2008

McGuire 2011

Subtotal (1-squared $=90.1 \%, p=0.001)$

12 months

McGuire 2005

Subtotal (1-squared $=\%, p=$.)

Overall (1-squared $=87.8 \%, p=0.000)$

NOTE: Weights are from random effects analysis

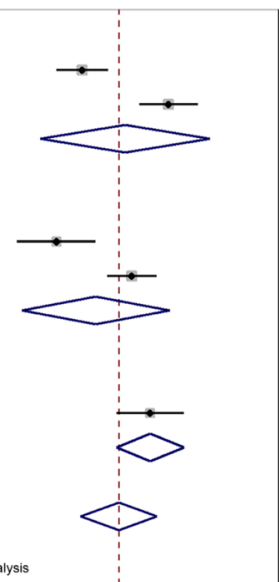

$1.82(-2.06,-1.58) \quad 20.81$

$-1.02(-1.29,-0.75) \quad 20.25$

$-1.42(-2.21,-0.64) \quad 41.05$

$-2.06(-2.42,-1.70) \quad 18.49$

$-1.36(-1.59,-1.13) \quad 20.97$

$-1.70(-2.38,-1.01) \quad 39.45$

$-1.19(-1.50,-0.88) \quad 19.48$

$-1.19(-1.50,-0.88) \quad 19.48$

$-1.48(-1.84,-1.13) \quad 100.00$ 
Fig. 2 a-c Forest plot on the tissue $\mathbf{a}$ color and $\mathbf{b}$ texture match and $\mathbf{c}$ patient preference after application of a FGG (=control) compared to a STS (=treatment) a

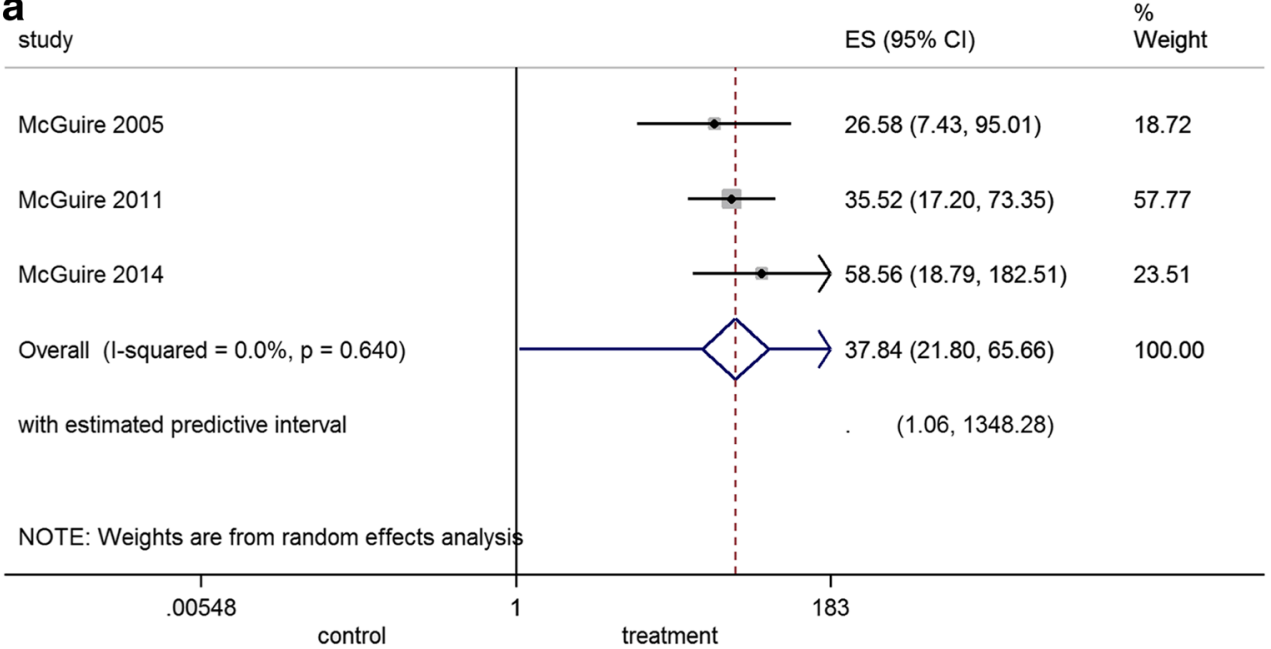

b

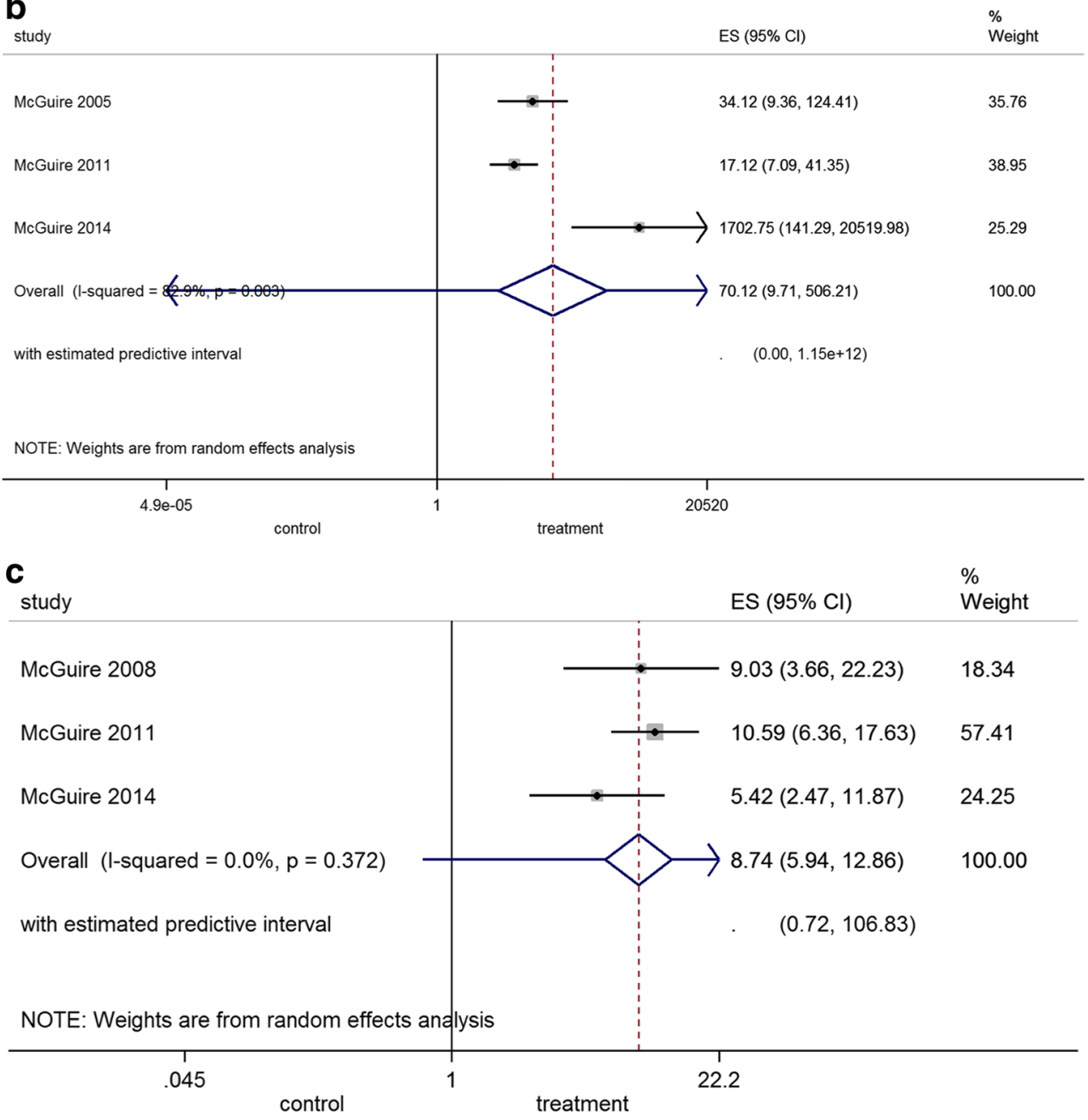

technique [11]. Thus, comparisons among studies, regarding the performance of the different STSs, have to be done with caution. Furthermore, when judging the currently available evidence on the topic, one has to take into account that only three of the included studies [12-14] where judged as of low
RoB. It is thus reasonable to require that future studies consistently and systematically follow the CONSORT guidelines for reporting of RCTs [38] and evaluate and report on the possible effect of anatomical and surgical factors (e.g., size of the recipient bed and vestibulum depth; treatment of single 
or multiple sites; application of single or multiple layers) and on relevant treatment outcomes (i.e., frequency of $\geq 2 \mathrm{~mm} \mathrm{KT}$ width postoperatively; PROMs).

In summary, the present systematic review and metaanalyses reached basically to similar conclusions as previous systematic reviews [3, 39] on with this topic:

- No preclinical in vivo studies comparing autogenous soft tissue grafts with a STS material are available.

- Use of STSs (acellular matrix or tissue engineered) in combination with APF resulted in a significantly less gain of KT width compared to what achieved with FGG and APF.

- Use of a tissue-engineered STS was apparently not superior to the use of an acellular matrix.

- Use of STS does not predictably result in a KT width $\geq 2 \mathrm{~mm}$ after treatment, while use of FGG does.

- Significantly better aesthetic outcomes and larger patient preference in favor of STS were observed.

- STS materials appeared to be safe.

Acknowledgments The authors wish to thank Michael K. McGuire (Houston, TX, USA), who kindly provided additional information on his studies. Further, additional product information was kindly provided by Keystone Dental (Burlington, USA) and BioHorizons (Birmingham, AL, USA)

\section{Compliance with ethical standards}

Conflict of interest The authors declare that they have no conflict of interest.

Funding No external funding was provided in regard with this study. The authors received no other institutional funding beyond their employment.

Ethical approval This article does not contain any studies with human participants or animals performed by any of the authors.

Informed consent For this type of study, formal consent is not required.

Open Access This article is distributed under the terms of the Creative Commons Attribution 4.0 International License (http:// creativecommons.org/licenses/by/4.0/), which permits unrestricted use, distribution, and reproduction in any medium, provided you give appropriate credit to the original author(s) and the source, provide a link to the Creative Commons license, and indicate if changes were made.

\section{References}

1. Kim DM, Neiva R (2015) Periodontal soft tissue non-root coverage procedures: a systematic review from the AAP regeneration workshop. J Periodontol 86:S56-S72
2. Scheyer ET, Sanz M, Dibart S et al (2015) Periodontal soft tissue non-root coverage procedures: a consensus report from the AAP regeneration workshop. J Periodontol 86:S73-S76

3. Thoma DS, Benic GI, Zwahlen M, Hammerle CH, Jung RE (2009) A systematic review assessing soft tissue augmentation techniques. Clin Oral Implants Res 20(Suppl 4):146-165

4. Miller SA, Forrest JL (2001) Enhancing your practice through evidence-based decision making: PICO, learning how to ask good questions. J Evid-Based Dent Pract 1:136-141

5. Liberati A, Altman DG, Tetzlaff J et al (2009) The PRISMA statement for reporting systematic reviews and meta-analyses of studies that evaluate health care interventions: explanation and elaboration. J Clin Epidemiol 62:e1-34

6. Moher D, Liberati A, Tetzlaff J, Altman DG (2009) Preferred reporting items for systematic reviews and meta-analyses: the PRISMA statement. PLoS Med 6:e1000097

7. Higgins JPT, Altman DG, Sterne JAC (2011) Chapter 8: assessing risk of bias in included studies. Cochrane handbook for systematic reviews of interventions Version 5.1.0 [updated March 2011] Available from http://www.cochrane-handbook.org/

8. Higgins JP, Thompson SG, Spiegelhalter DJ (2009) A re-evaluation of random-effects meta-analysis. J R Stat Soc Ser A Stat Soc 172: $137-159$

9. Deeks JJ, Higgins JPT, Altman DG (2011) Chapter 9: analysing data and undertaking meta-analyses. Cochrane handbook for systematic reviews of interventions Version 5.1.0

10. Harris RJ (2001) Clinical evaluation of 3 techniques to augment keratinized tissue without root coverage. J Periodontol 72:932-938

11. McGuire MK, Nunn ME (2005) Evaluation of the safety and efficacy of periodontal applications of a living tissue-engineered human fibroblast-derived dermal substitute. I. Comparison to the gingival autograft: a randomized controlled pilot study. J Periodontol 76:867-880

12. McGuire MK, Scheyer ET, Nunn ME, Lavin PT (2008) A pilot study to evaluate a tissue-engineered bilayered cell therapy as an alternative to tissue from the palate. J Periodontol 79:1847-1856

13. McGuire MK, Scheyer ET, Nevins ML et al (2011) Living cellular construct for increasing the width of keratinized gingiva: results from a randomized, within-patient, controlled trial. J Periodontol 82:1414-1423

14. McGuire MK, Scheyer ET (2014) Randomized, controlled clinical trial to evaluate a xenogeneic collagen matrix as an alternative to free gingival grafting for oral soft tissue augmentation. J Periodontol 85:1333-1341

15. Nevins M, Nevins ML, Camelo M, Camelo JM, Schupbach P, Kim DM (2010) The clinical efficacy of DynaMatrix extracellular membrane in augmenting keratinized tissue. Int J Periodontics Restor Dent 30:151-161

16. Nevins M, Nevins ML, Kim SW, Schupbach P, Kim DM (2011) The use of mucograft collagen matrix to augment the zone of keratinized tissue around teeth: a pilot study. Int J Periodontics Restor Dent 31:367-373

17. Wei PC, Laurell L, Geivelis M, Lingen MW, Maddalozzo D (2000) Acellular dermal matrix allografts to achieve increased attached gingiva. Part 1. A clinical study. J Periodontol 71:1297-1305

18. Sterne JAC, Egger M, Moher D (2011) Chapter 10: addressing reporting biases. Cochrane handbook for systematic reviews of interventions Version 5.1.0

19. Dorfman HS, Kennedy JE, Bird WC (1982) Longitudinal evaluation of free autogenous gingival grafts. A four year report. J Periodontol 53:349-352

20. Friedman N (1962) Mucogingival surgery: the apically repositioned flap. J Periodontol 33:328-340

21. Lang NP, Loe H (1972) The relationship between the width of keratinized gingiva and gingival health. J Periodontol 43:623-627 
22. Miyasato M, Crigger M, Egelberg J (1977) Gingival condition in areas of minimal and appreciable width of keratinized gingiva. $\mathrm{J}$ Clin Periodontol 4:200-209

23. Ochsenbein C (1960) Newer concept of mucogingival surgery. J Periodontol 31:175-185

24. Ruben MP (1979) A biological rationale for gingival reconstruction by grafting procedures. Quintessence Int 10:47-55

25. Wennström J, Lindhe J (1983) Plaque-induced gingival inflammation in the absence of attached gingiva in dogs. J Clin Periodontol 10:266-276

26. Wennström J, Lindhe J (1983) Role of attached gingiva for maintenance of periodontal health. Healing following excisional and grafting procedures in dogs. J Clin Periodontol 10:206-221

27. Kennedy JE, Bird WC, Palcanis KG, Dorfman HS (1985) A longitudinal evaluation of varying widths of attached gingiva. J Clin Periodontol 12:667-675

28. Agudio G, Nieri M, Rotundo R, Cortellini P, Pini Prato G (2008) Free gingival grafts to increase keratinized tissue: a retrospective long-term evaluation (10 to 25 years) of outcomes. J Periodontol 79:587-594

29. Agudio G, Nieri M, Rotundo R, Franceschi D, Cortellini P, Pini Prato GP (2009) Periodontal conditions of sites treated with gingival-augmentation surgery compared to untreated contralateral homologous sites: a 10- to 27-year long-term study. J Periodontol 80:1399-1405

30. Bates D, Kampa P (2013) Cell-based regenerative approaches to the treatment of oral soft tissue defects. Int J Oral Maxillofac Implants 28:e424-e431

31. Häkkinen L, Larjava H, Fournier BP (2014) Distinct phenotype and therapeutic potential of gingival fibroblasts. Cytotherapy 16:1171-1186

32. Morelli T, Neiva R, Nevins ML et al (2011) Angiogenic biomarkers and healing of living cellular constructs. J Dent Res 90:456-462

33. Nevins ML (2010) Tissue-engineered bilayered cell therapy for the treatment of oral mucosal defects: a case series. Int J Periodontics Restor Dent 30:31-39

34. Karring T, Ostergaard E, Löe H (1971) Conservation of tissue specificity after heterotopic transplantation of gingiva and alveolar mucosa. J Periodontal Res 6:282-293

35. Griffin TJ, Cheung WS, Zavras AI, Damoulis PD (2006) Postoperative complications following gingival augmentation procedures. J Periodontol 77:2070-2079

36. Keceli HG, Aylikci BU, Koseoglu S, Dolgun A (2015) Evaluation of palatal donor site haemostasis and wound healing after free gingival graft surgery. A randomized controlled clinical trial. J Clin Periodontol 42:582-589

37. Tan WC, Krishnaswamy G, Ong MM, Lang NP (2014) Patientreported outcome measures after routine periodontal and implant surgical procedures. J Clin Periodontol 41:618-624

38. Schulz KF, Altman DG, Moher D, CONSORT G (2010) CONSORT 2010 statement: updated guidelines for reporting parallel group randomised trials. PLoS Med 7:e1000251

39. Vignoletti F, Nunez J, Sanz M (2014) Soft tissue wound healing at teeth, dental implants and the edentulous ridge when using barrier membranes, growth and differentiation factors and soft tissue substitutes. J Clin Periodont 41:S23-S35

\section{References of excluded studies}

1. Carroll PB, Tow HD, Vernino AR (1974) The use of allogeneic freeze-dried skin grafts in the oral environment. A clinical and histologic evaluation. Oral Surg Oral Med Oral Pathol 37:163-174
2. Yukna RA, Sullivan WM (1978) Evaluation of resultant tissue type following the intraoral transplantation of various lyophilized soft tissues. J Periodontal Res 13:177-184

3. Novaes ABJ, Marchesan JT, Macedo GO, Palioto DB (2007) Effect of in vitro gingival fibroblast seeding on the in vivo incorporation of acellular dermal matrix allografts in dogs. J Periodontol 78:296-303

4. Jung RE, Hurzeler MB, Thoma DS, Khraisat A, Hammerle CH (2011) Local tolerance and efficiency of two prototype collagen matrices to increase the width of keratinized tissue. J Clin Periodontol $38: 173-179$

5. Lotfi G, Shokrgozar MA, Mofid R et al (2011) A clinical and histologic evaluation of gingival fibroblasts seeding on a chitosan-based scaffold and its effect on the width of keratinized gingiva in dogs. $\mathbf{J}$ Periodontol 82:1367-1375

6. Vignoletti F, Nunez J, de Sanctis F, Lopez M, Caffesse R, Sanz M (2014) Healing of a xenogeneic collagen matrix for keratinized tissue augmentation. Clin Oral Implants Res

7. von Weyhrother HG, Jacoby L, Mutscheilknauss R (1972) Use of lyophilized dura in mucogingival surgery. Dtsch Zahnarztl Z 27: 353-356

8. Koster HD, Flores de Jacoby L (1973) Comparative study of mucosal grafts and lyophilized dura. Dtsch Zahnarztl Z 28:1229

9. Krekeler G (1974) Using lyophilized dura in open vestibuloplasty. ZWR 83:639-641

10. Bernimoulin JP, Luscher B, Muhlemann HR (1975) Coronally repositioned periodontal flap. Clinical evaluation after one year J Clin Periodontol 2:1-13

11. Schoo WH, Coppes L (1976) Use of palatal mucosa and lyophilized dura mater to create attached gingiva. J Clin Periodontol 3:166-172

12. Yukna RA, Tow HD, Caroll PB, Vernino AR, Bright RW (1977) Comparative clinical evaluation of freeze-dried skin allografts and autogenous gingival grafts in humans. J Clin Periodontol 4:191-199

13. Yukna RA, Tow HD, Carroll PB, Vernino AR, Bright RW (1977) Evaluation of the use of freeze-dried skin allografts in the treatment of human mucogingival problems. J Periodontol 48:187-193

14. Matter J (1979) Free gingival graft and coronally repositioned flap. A 2-year follow-up report. J Clin Periodontol 6:437-442

15. Bartolucci EG (1981) A clinical evaluation of freeze-dried homologous dura mater as a periodontal free graft material. Study in humans. J Periodontol 52:354-361

16. Ouhayoun JP, Holzman S, Etienne D, Pierre C, Forest N (1983) Freeze-dried skin allografts. A human clinical and histological study. J Periodontol 54:463-469

17. Shulman J (1996) Clinical evaluation of an acellular dermal allograft for increasing the zone of attached gingiva. Pract Periodontics Aesthet Dent 8:201-208

18. Callan DP, Silverstein LH (1998) Use of acellular dermal matrix for increasing keratinized tissue around teeth and implants. Pract Periodontics Aesthet Dent 10:731-734

19. Haeri A, Clay J, Finely JM (1999) The use of an acellular dermal skin graft to gain keratinized tissue. Compend Contin Educ Dent 20(233-4):239

20. Haeri A, Parsell D (2000) Creeping attachment: autogenous graft vs dermal matrix allograft. Compend Contin Educ Dent 21:725-729 quiz 730

21. Wei PC, Laurell L, Lingen MW, Geivelis M (2002) Acellular dermal matrix allografts to achieve increased attached gingiva. Part 2. A histological comparative study. J Periodontol 73:257-265

22. Sezer B, Selcuk E, Erturk S, Gomel M (2004) Comparison of autogenous mucosal grafts and collagen-based, solvent-preserved allografts for vestibuloplasty. Quintessence Int 35:234-239

23. Mohammadi M, Shokrgozar MA, Mofid R (2007) Culture of human gingival fibroblasts on a biodegradable scaffold and evaluation of its effect on attached gingiva: a randomized, controlled pilot study. J Periodontol 78:1897-1903 
24. Sanz M, Lorenzo R, Aranda JJ, Martin C, Orsini M (2009) Clinical evaluation of a new collagen matrix (mucograft prototype) to enhance the width of keratinized tissue in patients with fixed prosthetic restorations: a randomized prospective clinical trial. J Clin Periodontol 36:868-876

25. Scarano A, Barros RR, Iezzi G, Piattelli A, Novaes ABJ (2009) Acellular dermal matrix graft for gingival augmentation: a preliminary clinical, histologic, and ultrastructural evaluation. J Periodontol 80:253-259

26. Vieira Ede O, Fidel Junior RA, Figueredo CM, Fischer RG (2009) Clinical evaluation of a dermic allograft in procedures to increase attached gingiva width. Braz Dent J 20:191-194

27. Nevins ML (2010) Tissue-engineered bilayered cell therapy for the treatment of oral mucosal defects: a case series. Int J Periodontics Restor Dent 30:31-39

28. Morelli T, Neiva R, Nevins ML et al (2011) Angiogenic biomarkers and healing of living cellular constructs. J Dent Res 90: $456-462$
29. Dominiak M, Lysiak-Drwal K, Saczko J, Kunert-Keil C, Gedrange $\mathrm{T}$ (2012) The clinical efficacy of primary culture of human fibroblasts in gingival augmentation procedures-a preliminary report. Ann Anat 194:502-507

30. George AM, Rajesh KS, Hegde S, Kumar A (2012) Two stage surgical procedure for root coverage. J Indian Soc Periodontol 16: 436-441

31. Izumi K, Neiva RF, Feinberg SE (2013) Intraoral grafting of tissue-engineered human oral mucosa. Int J Oral Maxillofac Implants 28:e295-e303

32. Scheyer ET, Nevins ML, Neiva R et al (2014) Generation of siteappropriate tissue by a living cellular sheet in the treatment of mucogingival defects. J Periodontol 85:e57-e64

33. Yadav N, Khattak BP, Misra S, Sharma A (2014) Comparative evaluation of the relative efficacy of the free mucosal graft and periosteal fenestration for increasing the vestibular depth - a clinical study. Contemp Clin Dent 5:366-370 